\title{
Chromohalobacter japonicus sp. nov., a moderately halophilic bacterium isolated from a Japanese salty food
}

Correspondence

Antonio Ventosa ventosa@us.es

\author{
Cristina Sánchez-Porro, ${ }^{1}$ Hiroko Tokunaga, ${ }^{2}$ Masao Tokunaga ${ }^{2}$ \\ and Antonio Ventosa ${ }^{1}$
}

\author{
${ }^{1}$ Department of Microbiology and Parasitology, Faculty of Pharmacy, University of Sevilla, 41012 \\ Sevilla, Spain \\ ${ }^{2}$ Laboratory of Applied and Molecular Microbiology, Faculty of Agriculture, Kagoshima University, \\ Kagoshima 890-0065, Japan
}

\begin{abstract}
A Gram-negative, non-spore-forming, rod-shaped, motile bacterium, designated strain $43^{\top}$, was isolated from a Japanese salty food and then subjected to a polyphasic taxonomic study. Strain $43^{\top}$ is moderately halophilic, growing at $\mathrm{NaCl}$ concentrations in the range $5-25 \%(\mathrm{w} / \mathrm{v})$, with optimum growth between 7.5 and $12.5 \%$ (w/v) NaCl. Growth occurs at temperatures from 15 to $42{ }^{\circ} \mathrm{C}$ (optimally at $28-37^{\circ} \mathrm{C}$ ) and at $\mathrm{pH} 5.5-9.0$ (optimally at $\mathrm{pH}$ 7.0-8.0). A phylogenetic analysis based on $16 \mathrm{~S}$ rRNA gene sequence comparisons revealed that strain $43^{\top}$ belongs to the genus Chromohalobacter. The closest relatives were Chromohalobacter canadensis ATCC $43984^{\top}$ (99.3\% 16S rRNA gene sequence similarity), Chromohalobacter beijerinckii ATCC $19372^{\top}(99.1 \%)$, Chromohalobacter sarecensis LV4 ${ }^{\top}$ (98.3\%), Chromohalobacter nigrandesensis LTS-4N ${ }^{\top}(97.9 \%)$ and Chromohalobacter marismortui ATCC $17056^{\top}(97.9 \%)$. The DNA G + C content was 62.9 mol\%, which is within the range described for the genus Chromohalobacter. DNA-DNA hybridization studies between strain $43^{\top}$ and C. canadensis CECT $5385^{\top}$ and C. beijerinckii DSM $7218^{\top}$ showed 38 and $49 \%$ relatedness, respectively; lower DNA-DNA hybridization percentages were obtained with respect to other related Chromohalobacter species. The major fatty acids of strain $43^{\top}$ were $C_{16: 0}, C_{19: 0}$ cyclo $\omega 8 \mathrm{c}$ and $\mathrm{C}_{12: 0} 3-\mathrm{OH}$. Overall, the phenotypic, genotypic and phylogenetic results demonstrated that strain $43^{\top}$ represents a novel species within the genus Chromohalobacter. The name Chromohalobacter japonicus sp. nov. is proposed, with strain $43^{\top}\left(=\mathrm{CECT} 7219^{\top}=\mathrm{CCM}\right.$ $7416^{\top}$ ) as the type strain.
\end{abstract}

The family Halomonadaceae includes the genera Halomonas, Carnimonas, Chromohalobacter, Cobetia and Zymobacter. These genera are members of the Gammaproteobacteria, within the order Oceanospirillales (Arahal \& Ventosa, 2006; Garrity et al., 2005). The genus Chromohalobacter was proposed by Ventosa et al. (1989) with a single species, Chromohalobacter marismortui, in order to include a halophilic bacterium previously described as 'Chromobacterium marismortui' (isolated from the Dead Sea by Elazari-Volcani, 1940) and several isolates from a saltern in Spain. Currently, the genus Chromohalobacter includes the species Chromohalobacter canadensis (Arahal et al., 2001a), C. israelensis (Arahal et al., 2001a), C. salexigens (Arahal et al., 2001b), C. sarecensis (Quillaguamán et al., 2004) and C. nigrandesensis (Prado et al., 2006). Recently, Peçonek et al. (2006) proposed the

The GenBank/EMBL/DDBJ accession number for the $16 \mathrm{~S}$ rRNA gene sequence of strain $43^{\top}$ is $A B 105159$. reclassification of Pseudomonas beijerinckii (Hof, 1935) as Chromohalobacter beijerinckii and emended the description of this species. The genus Chromohalobacter includes Gram-negative, straight or slightly curved, motile rods that are moderately halophilic, i.e. with optimum salt concentrations for growth between 8 and $10 \% \mathrm{NaCl}$. They are aerobic, catalase-positive and (in most species) oxidasenegative. They have been isolated from hypersaline environments such as the Dead Sea, salterns and saline soils (Ventosa, 2005). This genus represents a coherent phylogenetic cluster closely related to the genus Halomonas (Mellado et al., 1995; Arahal et al., 2002).

In this study, we have determined the taxonomic position of strain $43^{\mathrm{T}}$, which was isolated from a Japanese salty food in Shiokara (Onishi et al., 1980), as a novel member of the genus Chromohalobacter.

Strain $43^{\mathrm{T}}$ was isolated in SGC medium containing $4 \mathrm{M} \mathrm{NaCl}$ (Onishi et al., 1980). The strain was cultivated 
in SW10 medium with $10 \%(\mathrm{w} / \mathrm{v})$ total salts $(8.1 \% \mathrm{NaCl}$, $0.7 \% \mathrm{MgCl}_{2}, 0.96 \% \mathrm{MgSO}_{4}, 0.036 \% \mathrm{CaCl}_{2}, 0.2 \% \mathrm{KCl}$, $0.006 \% \mathrm{NaHCO}_{3}, 0.0026 \% \mathrm{NaBr}, 0.5 \%$ yeast extract; Difco) (Ventosa et al., 1982). The $\mathrm{pH}$ was adjusted to 7.2 with $1 \mathrm{M} \mathrm{KOH}$. When necessary, solid media were prepared by adding $2.0 \%(\mathrm{w} / \mathrm{v})$ Bacto agar (Difco).

Optimal conditions for growth were determined by growing strain $43^{\mathrm{T}}$ in $\mathrm{SW}$ medium at $0,2.5,5,7.5,10$, $12.5,15,17.5,20,25$ and $30 \%(\mathrm{w} / \mathrm{v})$ total salts at temperatures of $4,15,20,25,30,37,40,42$ and $45{ }^{\circ} \mathrm{C}$. The $\mathrm{pH}$ range for the isolate was tested in SW10 medium adjusted to $\mathrm{pH} 4.0,5.0,6.0,7.0,8.0,9.0$ and 10.0 using the appropriate buffers. The cells were cultivated with constant agitation (180 r.p.m.) and growth was monitored by measuring optical density at $600 \mathrm{~nm}$. The cells of strain $43^{\mathrm{T}}$ were found to be motile, Gram-negative, non-sporeforming rods. The cells were $1.2-4.5 \mu \mathrm{m}$ long and $0.4 \mu \mathrm{m}$ wide at the exponential phase of growth in SW10 medium at $37{ }^{\circ} \mathrm{C}$. Optimal growth occurred at $7.5-12.5 \%(\mathrm{w} / \mathrm{v})$ totals salts, $28-37{ }^{\circ} \mathrm{C}$ and $\mathrm{pH} 7.0-8.0$; the ranges for growth for strain $43^{\mathrm{T}}$ are shown in Table 1 .
To characterize the isolate phenotypically, standard tests (including those for determining the Gram reaction, cell morphology, motility and catalase and oxidase activities) were performed, along with other tests shown in Table 1 or included in the species description. Macroscopic properties were determined using the classical characterization of colony appearance. Biochemical tests were carried out at $10 \%$ total salts and $37{ }^{\circ} \mathrm{C}$, unless stated otherwise. Catalase activity was determined by adding a $1 \%$ (w/v) $\mathrm{H}_{2} \mathrm{O}_{2}$ solution to colonies on SW10 agar medium. An oxidase test was performed using the Dry Slide (Difco). Hydrolysis of starch, gelatin and Tween 80 and the production of urease were determined as described by Cowan \& Steel (1965) with the addition of $10 \%$ total salts to the medium. Citrate utilization was determined on Simmons' citrate medium supplemented with SW10. Acid production from carbohydrates was determined using phenol red base supplemented with $1 \%$ of the carbohydrate and SW10. Growth under anaerobic conditions was determined by incubating strain $43^{\mathrm{T}}$ in SW10 medium in an anaerobic chamber. Tests for sugar fermentation and enzymes were carried out using API 20NE and API ID 32E kits

Table 1. Characteristics that serve to distinguish strain $43^{\top}$ from recognized species of the genus Chromohalobacter

Strains: 1, strain $43^{\mathrm{T}} ; 2$, C. marismortui ATCC $17056^{\mathrm{T}} ; 3$, C. canadensis ATCC $43984^{\mathrm{T}}$; 4, C. beijerinckii DSM 7218 ${ }^{\mathrm{T}}$; 5, C. israelensis ATCC $43985^{\mathrm{T}}$; 6, C. salexigens DSM $3043^{\mathrm{T}}$; 7, C. sarecensis $\mathrm{LV}^{\mathrm{T}}$; 8, C. nigrandesensis DSM 5349 ${ }^{\mathrm{T}}$. Data are from Arahal et al. (2001a, b), Peçonek et al. (2006), Prado et al. (2006), Quillaguamán et al. (2004) and this study. +, Positive, -, negative, +/-, weak reaction; ND, no data available.

\begin{tabular}{|c|c|c|c|c|c|c|c|c|}
\hline Characteristic & 1 & 2 & 3 & 4 & 5 & 6 & 7 & 8 \\
\hline $\mathrm{NaCl}$ range for growth $(\%, w / v)$ & $5-25$ & $2-30$ & $3-25$ & $0.35-25$ & $3.5-20$ & $0.9-25$ & $0-25$ & $0.5-25$ \\
\hline Temperature range $\left({ }^{\circ} \mathrm{C}\right)$ & $15-42$ & $5-45$ & $15-45$ & $4-42$ & $15-45$ & $4-45$ & $0-45$ & $15-45$ \\
\hline Optimum temperature $\left({ }^{\circ} \mathrm{C}\right)$ & $28-37$ & 37 & 30 & 30 & 30 & 37 & $30-35$ & 32 \\
\hline Oxidase activity & - & + & - & + & - & - & + & - \\
\hline \multicolumn{9}{|l|}{ Acid production from: } \\
\hline Arabinose & - & - & + & + & + & + & - & + \\
\hline Maltose & + & + & - & - & + & + & - & - \\
\hline Sucrose & + & + & - & - & + & + & - & + \\
\hline $\mathrm{H}_{2} \mathrm{~S}$ production & - & - & - & - & - & + & - & + \\
\hline Indole production & - & - & + & - & + & - & - & $\mathrm{ND}$ \\
\hline \multicolumn{9}{|l|}{ Hydrolysis of: } \\
\hline Casein & - & - & - & - & - & + & - & ND \\
\hline Aesculin & - & - & + & - & + & $+1-$ & - & - \\
\hline Gelatin & + & - & - & - & - & $+1-$ & - & - \\
\hline Lysine decarboxylase & - & - & + & - & + & - & ND & ND \\
\hline Ornithine decarboxylase & + & - & + & - & + & - & ND & ND \\
\hline DNA G $+C$ content $(\mathrm{mol} \%)$ & 62.9 & 62.3 & 62 & 60.7 & 65 & 64.2 & 56.1 & 59.8 \\
\hline
\end{tabular}


(bioMérieux) inoculated according to the manufacturer's instructions, using the inoculated fluid at $10 \% \mathrm{NaCl}$ and with incubation at $37^{\circ} \mathrm{C}$.

The nutritional requirements of the isolate were determined using Biolog microplates. Strain $43^{\mathrm{T}}$ was grown on SW10 medium at $37{ }^{\circ} \mathrm{C}$ for $48 \mathrm{~h}$ and suspended in a $10 \%$ $\mathrm{NaCl}(\mathrm{w} / \mathrm{v})$ solution, within the density range specified by the manufacturer (model 21101 photometer; Biolog). Immediately after the cells had been suspended in the saline solution, the suspensions were transferred into sterile multichannel pipette reservoirs (Biolog) and the Biolog GN microplates were inoculated with $125 \mu \mathrm{l}$ cell suspension per well by means of an eight-channel repeating pipette. The inoculated Biolog plates were incubated at $37^{\circ} \mathrm{C}$ for 7 days and the results were read with a MicroPlate Reader using Microlog 3.59 software to perform automated readings. Antibiotic susceptibility was determined according to the conventional Kirby-Bauer method (Bauer et al., 1966). The phenotypic characteristics of strain $43^{\mathrm{T}}$ are included in the species description.

Chromosomal DNA was isolated and purified according to the method described by Marmur (1961). The 16S rRNA gene was amplified using the universal primers $16 \mathrm{~F} 27$ and 16R1488, as described by Mellado et al. (1995). The almostcomplete nucleotide sequence was determined by NBTNewbiotechnics (Seville, Spain) using an automated DNA sequencer (model 3100; Applied Biosystems) and was compared with reference 16S rRNA gene sequences retrieved from the GenBank and EMBL databases by BLAST searching. The subsequent sequence analysis was conducted using the ARB program package (Ludwig et al., 2004). Several treeing methods (maximum parsimony, distance matrix and maximum likelihood) were performed on the basis of the recommendations of Ludwig et al. (1998). A comparison based on the $16 \mathrm{~S}$ rRNA gene sequences from the databases revealed that the sequence $(1501 \mathrm{bp})$ of strain $43^{\mathrm{T}}$ displays the highest levels of similarity with those from
Chromohalobacter species. The closest relatives were C. canadensis ATCC $43984^{\mathrm{T}}$ ( $99.3 \%$ sequence similarity), C. beijerinckii ATCC $19372^{\mathrm{T}}(99.1 \%)$, C. sarecensis LV4 ${ }^{\mathrm{T}}$ $(98.3 \%)$ and C. marismortui ATCC $17056^{\mathrm{T}}(97.9 \%)$. Sequence similarities with respect to the other Chromohalobacter species were $\leqslant 96.6 \%$. The phylogenetic tree obtained by using the maximum-parsimony method shows strain $43^{\mathrm{T}}$ within the branch constituted by the Chromohalobacter species (Fig. 1). These results were consistent when other algorithms were used to construct phylogenetic trees.

Fatty acids were analysed at the BCCM/LMG (Ghent, Belgium) using GC (Kämpfer \& Kroppenstedt, 1996; Miller, 1982). Cells were cultured on TSA supplemented with $10 \%$ $\mathrm{NaCl}(\mathrm{w} / \mathrm{v})$ at $\mathrm{pH} 7.0$ and $37{ }^{\circ} \mathrm{C}$ for $24 \mathrm{~h}$. The predominant fatty acids of strain $43^{\mathrm{T}}$ were $\mathrm{C}_{16: 0}, \mathrm{C}_{19: 0}$ cyclo $\omega 8 \mathrm{c}$ and $\mathrm{C}_{12: 0} 3-\mathrm{OH}$. This composition is very similar to those described for recognized Chromohalobacter species, except that the $\mathrm{C}_{18: 1} \omega 7 c$ content is lower than for C. beijerinckii and C. marismortui (Table 2).

The $\mathrm{G}+\mathrm{C}$ content of the genomic DNA was determined from the mid-point value $\left(T_{\mathrm{m}}\right)$ of the thermal denaturation profile (Marmur \& Doty, 1962) using the equation of Owen \& Hill (1979), as previously described in detail by Ventosa et al. (1999). The DNA G + C content of strain $43^{\mathrm{T}}$ was found to be $62.9 \mathrm{~mol} \%$, which is within the range for species belonging to the genus Chromohalobacter (Ventosa, 2005).

DNA-DNA hybridization studies were performed by using the competition procedure of the membrane method (Johnson, 1994), described in detail by Mormile et al. (1999). The hybridization temperature was $58.1{ }^{\circ} \mathrm{C}$, which is within the limit of validity for the filter method (De Ley \& Tijtgat, 1970), and the percentage of hybridization was calculated according to Johnson (1994). The experiments were carried out in triplicate. The percentage of DNADNA hybridization between strain $43^{\mathrm{T}}$ and C. canadensis

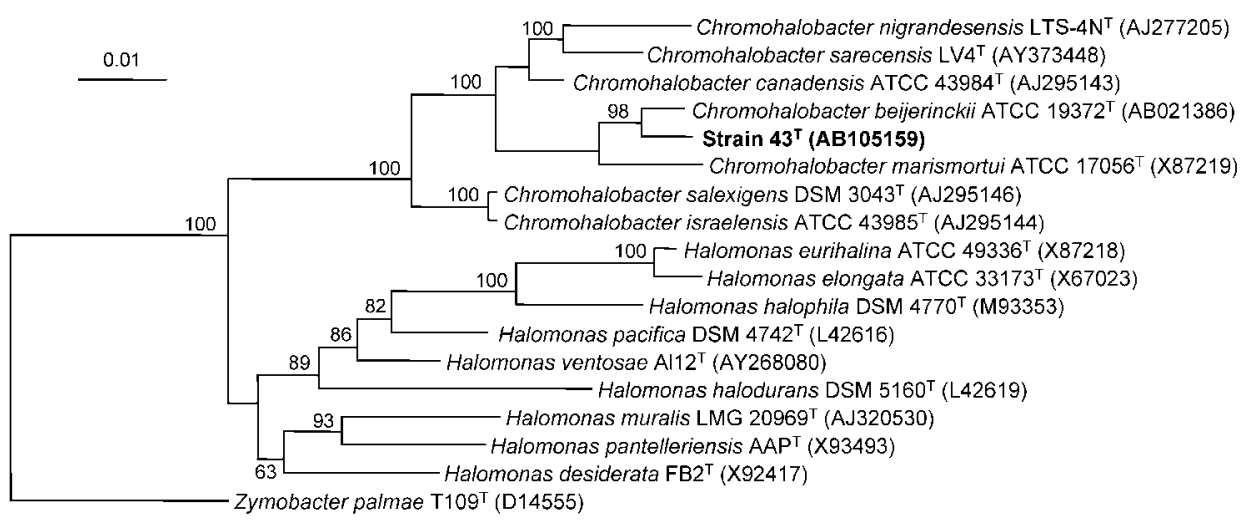

Fig. 1. Maximum-parsimony phylogenetic tree, based on $16 \mathrm{~S}$ rRNA gene sequences of strain $43^{\top}$ and closely related species. Sequence accession numbers used are shown in parentheses. Bootstrap values $>50 \%$ are indicated at branch-points.

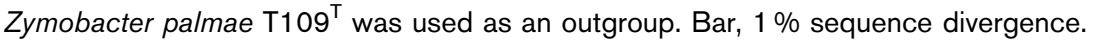


Table 2. Cellular fatty acid compositions (\%) of strain $43^{\top}, C$ beijerinckii DSM $7218^{\top}$ and C. marismortui DSM $6770^{\top}$

Data for C. marismortui DSM $6770^{\mathrm{T}}$ and C. beijerinckii DSM $7218^{\mathrm{T}}$ were taken from Peçonek et al. (2006). ND, Not detected; ECL, equivalent chain-length.

\begin{tabular}{|lccc|}
\hline Fatty acid & Strain $\mathbf{4 3}^{\mathbf{T}}$ & $\begin{array}{c}\text { C. beijerinckii } \\
\text { DSM } \mathbf{7 2 1 8}^{\mathbf{T}}\end{array}$ & $\begin{array}{c}\text { C. marismortui } \\
\text { DSM } \mathbf{6 7 7 0}^{\mathbf{T}}\end{array}$ \\
\hline $\mathrm{C}_{10: 0}$ & 3.3 & 2.1 & 2.2 \\
$\mathrm{C}_{12: 0}$ & $\mathrm{ND}$ & $\mathrm{ND}$ & 0.2 \\
Unknown ECL & 0.2 & $\mathrm{ND}$ & 0.4 \\
11.799 & & & \\
$\mathrm{C}_{12: 0}$ & 4.3 & 3.1 & 3.6 \\
$\mathrm{C}_{12: 0}$ 3-OH & 10.4 & 7.1 & 8.2 \\
$\mathrm{C}_{14: 0}$ & 0.6 & 0.4 & $\mathrm{ND}$ \\
Summed feature $3 *^{*}$ & 1.8 & 5.0 & 6.0 \\
$\mathrm{C}_{16: 0}$ & 34.6 & 27.6 & 18.0 \\
$\mathrm{C}_{17}$ cyclo & 7.5 & 10.4 & 3.6 \\
$\mathrm{C}_{18: 1} \omega 7 c$ & 5.0 & 11.0 & 29.8 \\
$\mathrm{C}_{18: 0}$ & 1.4 & 0.4 & 0.8 \\
$\mathrm{C}_{18: 1} \omega 7 c$ 11-methyl & 0.4 & 1.0 & 1.2 \\
$\mathrm{C}_{19}$ cyclo $\omega 8 c$ & 29.8 & 31.4 & 25.5 \\
$\mathrm{C}_{20: 2} \omega 6,9 c$ & 0.3 & 0.6 & 0.7 \\
\hline
\end{tabular}

*Summed features are groups of fatty acids that could not be resolved chromatographically; summed feature 3 consists of $\mathrm{C}_{16: 1} \omega 7 c$ and/or $\mathrm{C}_{15: 0}$ iso $2-\mathrm{OH}$.

CECT $5385^{\mathrm{T}}$ was $38 \%$, while those between strain $43^{\mathrm{T}}$ and C. beijerinckii DSM $7218^{\mathrm{T}}$, C. marismortui ATCC $17056^{\mathrm{T}}$, C. sarecensis $\mathrm{LV}^{\mathrm{T}}$ and C. nigrandesensis $\mathrm{LTS}-4 \mathrm{~N}^{\mathrm{T}}$ were 49 , 33,32 and $28 \%$, respectively. These levels of DNA-DNA hybridization are low enough to justify classifying strain $43^{\mathrm{T}}$ as a member of a genotypically distinct species within the genus Chromohalobacter (Stackebrandt \& Goebel, 1994; Stackebrandt et al., 2002). In addition, these genotypic differences are supported by the presence of phenotypic features that can be used to differentiate strain $43^{\mathrm{T}}$ from related species of the genus Chromohalobacter (Table 1).

Overall, the phenotypic, phylogenetic and genotypic results presented in this study demonstrate that strain $43^{\mathrm{T}}$ represents a novel species within the genus Chromohalobacter, for which the name Chromohalobacter japonicus sp. nov. is proposed.

\section{Description of Chromohalobacter japonicus sp. nov.}

Chromohalobacter japonicus (ja.po'ni.cus. N.L. masc. adj. japonicus Japanese).

Cells are Gram-negative, non-spore-forming, straight or sometimes slightly curved, motile rods that are $0.4 \times 1.2$ $4.5 \mu \mathrm{m}$ in size and occur singly, in pairs and in short chains. Colonies on SW10 medium after 2 days incubation at $37{ }^{\circ} \mathrm{C}$ are $0.5 \mathrm{~mm}$ in diameter, cream, circular, regular and convex with an entire margin. Moderately halophilic, growing at $\mathrm{NaCl}$ concentrations in the range $5-25 \%(\mathrm{w} / \mathrm{v})$, with an optimum between 7.5 and 12.5 (w/v) NaCl. Growth occurs at temperatures from 15 to $42{ }^{\circ} \mathrm{C}$ (optimally at 28$37^{\circ} \mathrm{C}$ ) and at pH 5.5-9.0 (optimally at pH 7.0-8.0). Strictly aerobic. Catalase is produced. Negative for indole production, the Voges-Proskauer test, $\mathrm{H}_{2} \mathrm{~S}$ production, starch, casein, aesculin, DNA and Tween 80 hydrolysis, urease activity and oxidase activity. Gelatin is hydrolysed. Methyl red-positive. Nitrate is reduced to nitrite but nitrite is not reduced. Positive for the Simmons' citrate test. Acid is produced from D-galactose, mannose, D-glucose, maltose, xylose, galacturonate, adonitol, palatinose, sucrose, Darabitol, L-rhamnose, inositol, D-cellobiose and D-sorbitol but not from arabinose, D-fructose, glycerol, D-mannitol, trehalose, sorbitol, L-arabitol or 5-ketogluconate. Positive for ornithine decarboxylase and L-aspartic acid arylamidase. Negative for arginine dihydrolase, $\beta$-galactosidase, lysine decarboxylase, $\beta$-glucosidase, $\beta$-glucuronidase, $N$ acetyl- $\beta$-glucosaminidase, $\alpha$-glucosidase, $\alpha$-galactosidase and $\alpha$-maltosidase. The following compounds are used as sole carbon and energy sources (Biolog): L-arabinose, Dfructose, D-galactose, gentiobiose, $\alpha$-D-glucose, D-mannitol, D-psicose, L-rhamnose, cis-aconitic acid, citric acid, Dgluconic acid, D-glucosaminic acid, $\alpha$-ketoglutaric acid, DL-lactic acid, succinamic acid, D-alanine, L-alanyl glycine, L-asparagine, L-aspartic acid, L-glutamic acid, glycyl Laspartic acid, glycyl L-glutamic acid, L-histidine, L-proline, L-pyroglutamic acid, L-serine, L-threonine and glycerol. The following compounds are not used as sole carbon and energy sources (Biolog): $\alpha$-cyclodextrin, dextrin, glycogen, Tween 40 , Tween $80, N$-acetyl-D-galactosamine, $N$-acetylD-glucosamine, adonitol, D-arabitol, cellobiose, i-erythritol, L-fucose, myo-inositol, $\alpha$-D-lactose, lactulose, maltose, Dmannose, D-melibiose, methyl $\beta$-D-glucoside, D-raffinose, D-sorbitol, sucrose, trehalose, turanose, xylitol, methyl pyruvate, monomethyl succinate, acetic acid, formic acid, D-galactonic acid lactone, D-galacturonic acid, D-glucuronic acid, $\alpha$-hydroxybutyric acid, $\beta$-hydroxybutyric acid, $\gamma$ hydroxybutyric acid, $p$-hydroxyphenylacetic acid, itaconic acid, $\alpha$-ketobutyric acid, $\alpha$-ketovaleric acid, malonic acid, propionic acid, quinic acid, D-saccharic acid, sebacic acid, succinic acid, bromosuccinic acid, glucuronamide, alaninamide, L-alanine, hydroxy-L-proline, L-leucine, L-ornithine, L-phenylalanine, D-serine, DL-carnitine, $\gamma$-aminobutyric acid, urocanic acid, inosine, uridine, thymidine, phenylethylamine, putrescine, 2-aminoethanol, 2,3-butanediol, DL- $\alpha$-glycerol phosphate, glucose 1-phosphate and glucose 6-phosphate. Resistant to ( $\mu \mathrm{g}$ per disc, unless specified otherwise): penicillin $\mathrm{G}(10 \mathrm{U})$, bacitracin (10 U), cephalothin (30), rifampicin (30), streptomycin (10), neomycin (10), erythromycin (15), kanamycin (30), vancomycin (30), nalidixic acid (30), novobiocin (30), polymyxin B (300 U) and chloramphenicol (30). Susceptible to sulfamethoxazole/trimethoprim (23.75/1.25 $\mu \mathrm{g}$ per disc). The major fatty acids are $\mathrm{C}_{16: 0}, \mathrm{C}_{19: 0}$ cyclo $\omega 8 \mathrm{c}$ and $\mathrm{C}_{12: 0}$ 3-OH. The DNA G + C content is $62.9 \mathrm{~mol} \%$. 
The type strain, $43^{\mathrm{T}}\left(=\right.$ CECT $7219^{\mathrm{T}}=$ CCM $\left.7416^{\mathrm{T}}\right)$, was isolated from a Japanese salty food.

\section{Acknowledgements}

This work was supported by grants from the Quality of Life and Management of Living Resources Programme of the European Commission (QLK3-CT-2002-01972), the Spanish Ministerio de Educación y Ciencia (BIO2006-006927) and the Junta de Andalucía.

\section{References}

Arahal, D. R. \& Ventosa, A. (2006). The family Halomonadaceae. In The Prokaryotes: a Handbook on the Biology of Bacteria, 3rd edn, vol. 6, pp. 811-835. Edited by M. Dworkin, S. Falkow, E. Rosenberg, K. H. Schleifer \& E. Stackebrandt. New York: Springer.

Arahal, D. R., Garcia, M. T., Ludwig, W., Schleifer, K. H. \& Ventosa, A. (2001a). Transfer of Halomonas canadensis and Halomonas israelensis to the genus Chromohalobacter as Chromohalobacter canadensis comb. nov. and Chromohalobacter israelensis comb. nov. Int J Syst Evol Microbiol 51, 1443-1448.

Arahal, D. R., Garcia, M. T., Vargas, C., Canovas, D., Nieto, J. J. \& Ventosa, A. (2001b). Chromohalobacter salexigens sp. nov., a moderately halophilic species that includes Halomonas elongata DSM 3043 and ATCC 33174. Int J Syst Evol Microbiol 51, 1457-1462.

Arahal, D. R., Ludwig, W., Schleifer, K. H. \& Ventosa, A. (2002). Phylogeny of the family Halomonadaceae based on 23S and 16S rDNA sequence analyses. Int J Syst Evol Microbiol 52, 241-249.

Bauer, A. W., Kirby, W. M. M., Sherris, J. C. \& Turck, M. (1966). Antibiotic susceptibility testing by a standardized single disk method. Am J Clin Pathol 45, 493-496.

Cowan, S. T. \& Steel, K. J. (1965). Manual for the Identification of Medical Bacteria. London: Cambridge University Press.

De Ley, J. \& Tijtgat, R. (1970). Evaluation of membrane filter methods for DNA-DNA hybridization. Antonie van Leeuwenhoek 36, 461-474.

Elazari-Volcani, B. (1940). Studies on the microflora of the Dead Sea. $\mathrm{PhD}$ thesis, Hebrew University of Jerusalem.

Garrity, G. M., Bell, J. A. \& Lilburn, T. (2005). Family IV. Halomonadaceae Franzmann, Wehmeyer and Stackebrandt 1989, $205^{\mathrm{VP}}$ emend. Dobson and Franzmann 1996, 558. In Bergey's Manual of Systematic Bacteriology, 2nd edn, vol. 2, part B, p. 300. Edited by D. J. Brenner, N. R. Krieg, J. T. Staley \& G. M. Garrity. New York: Springer.

Hof, T. (1935). An investigation of the microorganisms commonly present in salted beans. Rec Trav Bot Neerl 32, 151-173.

Johnson, J. L. (1994). Similarity analysis of DNAs. In Methods for General and Molecular Bacteriology, pp. 655-681. Edited by P. Gerhardt, R. G. E. Murray, W. A. Wood \& N. R. Krieg. Washington, DC: American Society for Microbiology.

Kämpfer, P. \& Kroppenstedt, R. M. (1996). Numerical analysis of fatty acid patterns of coryneform bacteria and related taxa. Can J Microbiol 42, 989-1005.

Ludwig, W., Strunk, O., Klugbauer, S., Klugbauer, N., Weizenernegger, M., Neumaier, J., Bachleitner, M. \& Schleifer, K.-H. (1998). Bacterial phylogeny based on comparative sequence analysis. Electrophoresis 19, 554-568.

Ludwig, W., Strunk, O., Westram, R., Richter, L., Meier, H., Yadhukumar, Buchner, A., Lai, T., Steppi, S. \& other authors (2004). ARB: a software environment for sequence data. Nucleic Acids Res 32, 1363-1371.
Marmur, J. (1961). A procedure for the isolation of deoxyribonucleic acid from microorganisms. J Mol Biol 3, 208-218.

Marmur, J. \& Doty, P. (1962). Determination of the base composition of deoxyribonucleic acid from its thermal denaturation temperature. J Mol Biol 5, 109-118.

Mellado, E., Moore, E. R. B., Nieto, J. J. \& Ventosa, A. (1995). Phylogenetic inferences and taxonomic consequences of $16 \mathrm{~S}$ ribosomal DNA sequence comparison of Chromohalobacter marismortui, Volcaniella eurihalina, and Deleya salina and reclassification of $V$. eurihalina as Halomonas eurihalina comb. nov. Int J Syst Bacteriol 45, 712-716.

Miller, L. T. (1982). Single derivation method for routine analysis of bacterial whole-cell fatty acid methyl esters, including hydroxyl acids. J Clin Microbiol 16, 584-586.

Mormile, M. R., Romine, M. F., Garcia, M. T., Ventosa, A., Bailey, T. J. \& Peyton, B. M. (1999). Halomonas campisalis sp. nov., a denitrifying, moderately haloalkaliphilic bacterium. Syst Appl Microbiol 22, 551-558.

Onishi, H., Fuchi, H., Konomi, K., Hidaka, O. \& Kamekura, M. (1980). Isolation and distribution of a variety of halophilic bacteria and their classification by salt-response. Agric Biol Chem 44, 1253-1258.

Owen, R. J. \& Hill, L. R. (1979). The estimation of base compositions, base pairing and genome sizes of bacterial deoxyribonucleic acids. In Identification Methods for Microbiologists, 2nd edn, pp. 277-296. Edited by F. A. Skinner \& D. W. Lovelock. London: Academic Press.

Peçonek, J., Gruber, C., Gallego, V., Ventosa, A., Busse, H.-J., Kämpfer, P., Radax, C. \& Stan-Lotter, H. (2006). Reclassification of Pseudomonas beijerinckii Hof 1935 as Chromohalobacter beijerinckii comb. nov., and emended description of the species. Int J Syst Evol Microbiol 56, 1953-1957.

Prado, B., Lizama, C., Aguiler, M., Ramos-Cormenzana, A., Fuentes, S., Campos, V. \& Monteoliva-Sanchez, M. (2006). Chromohalobacter nigrandesensis sp. nov., a moderately halophilic, Gram-negative bacterium isolated from Lake Tebenquiche on the Atacama Saltern, Chile. Int J Syst Evol Microbiol 56, 647-651.

Quillaguamán, J., Delgado, O., Mattiasson, B. \& Hatti-Kaul, R. (2004). Chromohalobacter sarecensis sp. nov., a psychrotolerant moderate halophile isolated from the saline Andean region of Bolivia. Int J Syst Evol Microbiol 54, 1921-1926.

Stackebrandt, E. \& Goebel, B. M. (1994). Taxonomic note: a place for DNA-DNA reassociation and $16 \mathrm{~S}$ rRNA sequence analysis in the present species definition in bacteriology. Int J Syst Bacteriol 44, 846-849.

Stackebrandt, E., Fredericksen, W., Garrity, G. M., Grimont, P. A. D., Kämpfer, P., Maiden, M. C. J., Nesme, X., Rosselló-Mora, R., Swings, J. \& other authors (2002). Report of the ad hoc committee for the reevaluation of the species definition in bacteriology. Int J Syst Evol Microbiol 52, 1043-1047.

Ventosa, A. (2005). Genus III. Chromohalobacter Ventosa, Gutierrez, García and Ruiz-Berraquero 1989, 384 ${ }^{\mathrm{VP}}$ emend. Arahal, García, Ludwig, Schleifer and Ventosa 2001a, 1446. In Bergey's Manual of Systematic Bacteriology, 2nd edn, vol. 2, part B, pp. 316-319. Edited by D. J. Brenner, N. R. Krieg, J. T. Staley \& G. M. Garrity. New York: Springer.

Ventosa, A., Quesada, E., Rodriguez-Valera, F., Ruiz-Berraquero, F. \& Ramos-Cormenzana, A. (1982). Numerical taxonomy of moderately halophilic Gram-negative rods. J Gen Microbiol 128, 1959-1968.

Ventosa, A., Gutierrez, M. C., Garcia, M. T. \& Ruiz-Berraquero, F. (1989). Classification of "Chromobacterium marismortui" in a new genus, Chromohalobacter gen. nov., as Chromohalobacter marismortui comb. nov., nom. rev. Int J Syst Bacteriol 39, 382-386.

Ventosa, A., Gutierrez, M. C., Kamekura, M. \& Dyall-Smith, M. L. (1999). Proposal to transfer Halococcus turkmenicus, Halobacterium trapanicum JCM 9743 and strain GSL-11 to Haloterrigena turkmenica gen. nov., comb. nov. Int J Syst Bacteriol 49, 131-136. 